\title{
MARKETING VIGILANCE AND ITS ROLE IN AMBIDEXTERITY PERFORMANCE APPLIED RESEARCH IN BAGHDAD COMPANY FOR SOFT DRINKS
}

\author{
Sahera Mohammed Hassan \\ Assistant Professor, College of Administration and Economics and Al Mamon College \\ Business Management, University of Baghdad, Iraq, Baghdad. \\ Dr. Fadheela Salman Dawood \\ Professor, College of Administration and Economics, University of Baghdad, Iraq, Baghdad.
}

\begin{abstract}
The research aims to shed light on the role of marketing vigilance in ambidextrous performance, as the research was applied in the Baghdad Soft Drinks Company as a research community, and the research sample was chosen from the department managers in the company for the purpose of collecting information through a personal interview. The scientific approach followed is a case study, in order to address the problem that the company suffers from, which is the gap between the real reality of the company and what it wants in the future. (0.44), which is a very high percentage that needs to be addressed by the company, which led to an increase in the rate of weakness in performance and a lack of creative performance among the employees of the company, as the size of the gap reached (16.7), which is a high percentage..
\end{abstract}

Keywords: marketing vigilance, mental image, marketing intelligence, ambidextrous performance, exploration opportunities, exploitation opportunities, creative performance.

Cite this Article Sahera Mohammed Hassan and Fadheela Salman Dawood, Marketing Vigilance and its Role in Ambidexterity Performance Applied Research in Baghdad Company for Soft Drinks, International Journal of Management 11(12), 2020, pp 1286-1306.

http://iaeme.com/Home/issue/IJM?Volume=11\&Issue $=12$ 
Marketing Vigilance and its Role in Ambidexterity Performance Applied Research in Baghdad Company for Soft Drinks

\section{INTRODUCTION}

\subsection{The scientific methodology for research}

The methodology of scientific research is considered as a road map for the researcher, through which he can determine the correct path of research, and through this map the researcher can determine the details that will be researched in order to achieve the research objectives, and thus come up with results that serve the research community and sample, as the research aims to define The research problem, its importance, its objectives, the hypothetical outline of the research, and its hypotheses, in addition to the research scale to collect information, as follows:

\subsubsection{The research problem}

Organizations live in light of environmental tensions and uncertainty with excessive competitiveness that calls for strategic analysis and study of factors affecting their work. Organizations must be alert to these variables and factors that affect the organization's work environment, and this indicates the lack of interest of the responsible authorities in the company in these factors, and the research problem has been formulated. With the following questions:

- What is the level of availability of marketing vigilance at the research sample company?

- What is the level of availability of the ambidextrous performance indicators of the researched company?

- What is the extent of the influence of marketing vigilance in each dimension of ambidextrous performance?

- What is the level of relationship between marketing alertness and ambidextrous performance?

\subsubsection{The importance of research}

- Attracting the attention and vigilance of the company's managers on the main and subvariables of marketing vigilance and ambidextrous performance because of its role in building the entrepreneurial capital of the company in question.

- The research acquires its importance from the importance of the topic covered, as the researched company faces challenges in its competitive environment, as there are many products (especially soft drinks and mineral water) with global, Arab and local origins.

\subsubsection{Research objectives}

The main objective of the research marked is the ambidextrous performance according to the marketing vigilance of the Iraqi Industrial Company, represented by the research sample, which is the Baghdad Soft Drinks Company.

- Clarify the extent of the availability of the dimensions of the marketing vigilance of Baghdad Soft and Mineral Drinks Company at the overall level.

- Attempt to highlight the effect of vigilance marketing on ambidextrous performance.

- Clarify the relationship between marketing vigilance and ambidextrous performance.

\subsubsection{The hypothetical outline of the research}


From the standpoint of the problem and the objectives of the research, the research scale was designed according to the scientific literature in the field of marketing and strategic management, as in the following scheme:

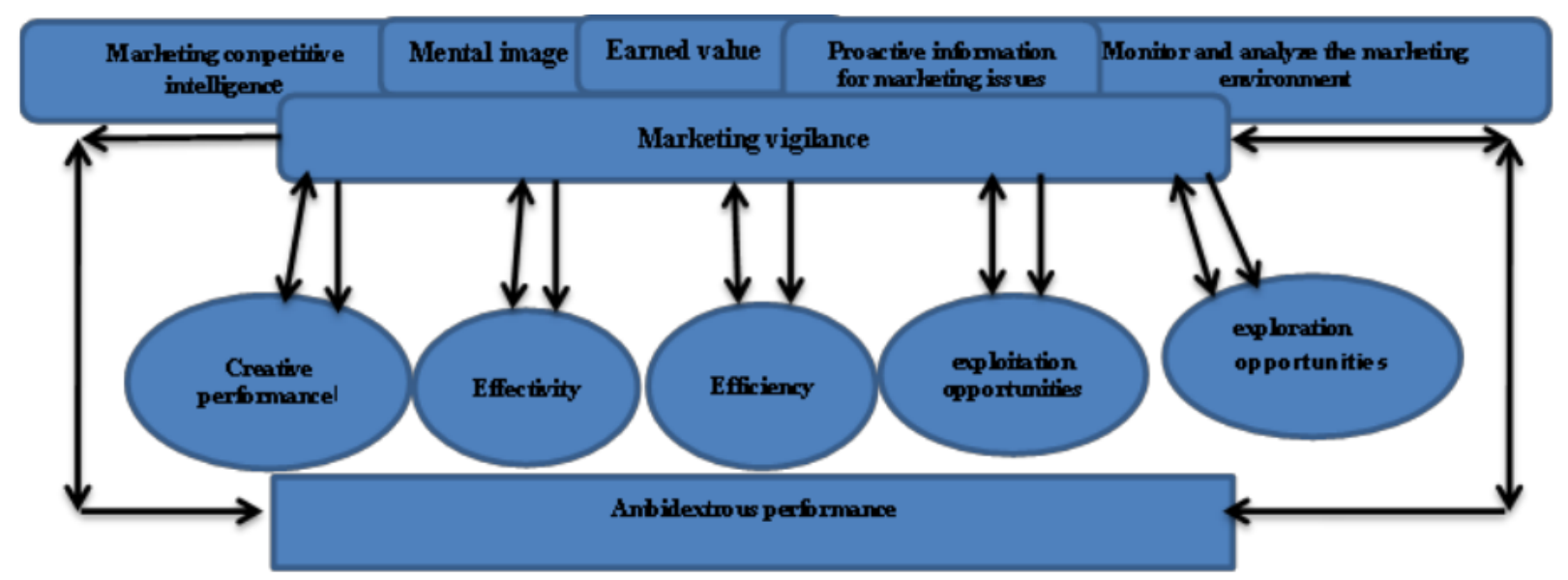

Figure 1. Marketing and strategic management

\subsubsection{Research hypotheses.}

The research hypotheses were based on the hypothesis outline of the research, as follows:

The first main hypothesis: There is no statistically significant correlation between marketing vigilance and ambidextrous performance in its dimensions.

The second main hypothesis: There is no statistically significant effect of marketing vigilance and ambidextrous performance in its dimensions.

\subsubsection{Designing the Research Scale}

The research scale was designed according to the scientific literature in the field of marketing and strategic management, as follows:

Table1.The design of the research scale

\begin{tabular}{|c|c|c|c|}
\hline Source & $\begin{array}{l}\text { Number } \\
\text { item }\end{array}$ & Dimensions & $\begin{array}{l}\text { Main variables } \\
\text { and dimensions }\end{array}$ \\
\hline \multirow[t]{6}{*}{ Hussein: 2020, Yamina 2017} & 25 & \multicolumn{2}{|l|}{ Marketing vigilance } \\
\hline & 5 & $\begin{array}{l}\text { Monitor and analyze the marketing } \\
\text { environment }\end{array}$ & \\
\hline & 5 & $\begin{array}{l}\text { Proactive information for marketing } \\
\text { issues }\end{array}$ & \\
\hline & 5 & Earned value & \\
\hline & 5 & Mental image & \\
\hline & 5 & Marketing competitive intelligence & \\
\hline \multirow{4}{*}{$\begin{array}{l}\text { Dawood: } 2017 \text {, Abdul Karim 2020, Abdul- } \\
\text { Jabbar: } 2020\end{array}$} & 20 & \multicolumn{2}{|l|}{ ambidextrous performance } \\
\hline & 4 & Exploitation opportunities & \\
\hline & 4 & exploration opportunities, & \\
\hline & 4 & Efficiency & \\
\hline
\end{tabular}


Marketing Vigilance and its Role in Ambidexterity Performance Applied Research in Baghdad Company for Soft Drinks

\begin{tabular}{|l|l|l|l|}
\hline & 4 & Effectivity & \\
\cline { 2 - 3 } & 4 & Creative performancel & \\
\hline
\end{tabular}

\subsubsection{Society and Research Sample:}

The soft and mineral drinks company was chosen as the research community, and a sample of leaders and directors of departments, divisions and units in the company was chosen, and questions were asked to them for the purpose of collecting information and data on the basis of which the checklist was designed, which was considered the main tool for the search

\section{VIGILANCE MARKETING}

Where the topic deals with the concept of marketing vigilance, its importance, objectives, types, and dimensions as follows:

\subsection{The concept of marketing vigilance}

It is a type of strategic vigilance that means the process of research, processing and distribution of information about the organization's markets, specifically following-up market development and consumer behavior and introducing new products in this type of vigilance. Focus is on the changing needs of the customer, the development of the relationship between the organization and the customer, the development of new products, and the evolution of the relationship between the suppliers and the organization, and the possibility of obtaining the supplier the products requested by the organization at a lower cost (Dawood \& Abbas, 2018: 7). As indicated (Daoud and Ibrahim, 2017: 51), it is a series of continuous and repetitive processes through which organizations can monitor and analyze their marketing environment to obtain potential indicators related to opportunities and threats that affect the survival of the organization, and use vigilance in making decisions aimed at improving the performance of the organization.

Table 2 The contributions of researchers in the field of defining marketing vigilance for the period (2011-2020.)

\begin{tabular}{|c|c|c|}
\hline concentration & the definition & reseach \\
\hline $\begin{array}{l}\text { Market monitoring and } \\
\text { control }\end{array}$ & $\begin{array}{l}\text { It is concerned with monitoring and controlling the markets } \\
\text { in which the organization operates, where information is } \\
\text { collected and the organization's position in the markets is } \\
\text { identified, customer behaviors are determined, new markets } \\
\text { are also identified and new products are introduced to } \\
\text { customers. }\end{array}$ & Miaux,2011:15 \\
\hline $\begin{array}{l}\text { Monitor and control the } \\
\text { marketing environment. }\end{array}$ & $\begin{array}{l}\text { Study and control the marketing environment for products } \\
\text { (goods, services) and their operation. }\end{array}$ & Blanc,2013:7 \\
\hline $\begin{array}{l}\text { Determine the marketing } \\
\text { path, win competitive } \\
\text { challenges, and face } \\
\text { marketing risks. }\end{array}$ & $\begin{array}{l}\text { A group process that is proactive, the purpose of which is } \\
\text { to define the marketing course of the organization through } \\
\text { knowing the environment in which the organization } \\
\text { operates, and collecting the necessary information that } \\
\text { helps the management of the organization in facing risks } \\
\text { and winning competitive challenges. }\end{array}$ & Muniz et al.,2017:4 \\
\hline $\begin{array}{l}\text { Research and processing } \\
\text { of marketing information }\end{array}$ & $\begin{array}{l}\text { The process of searching for information, then processing } \\
\text { and distributing it on the organization's markets, } \\
\text { monitoring and controlling market development, consumer } \\
\text { behavior and introducing new products. Here, focus is on } \\
\text { the long-term changing needs of customers, the }\end{array}$ & $\begin{array}{l}\text { Dawood\& } \\
\text { Abbas, } 2018: 7\end{array}$ \\
\hline
\end{tabular}




\begin{tabular}{|l|l|l|}
\hline & $\begin{array}{l}\text { development of the relationship between the organization } \\
\text { and customers, the development of new products and the } \\
\text { possibility of obtaining resources at a lower cost. }\end{array}$ & \\
\hline $\begin{array}{l}\text { Monitor the movements } \\
\text { and trends of customers } \\
\text { and suppliers } \\
\text { ongoing process }\end{array}$ & $\begin{array}{l}\text { It is also called commercial vigilance, and it is concerned } \\
\text { with studying both the customers who are known in the } \\
\text { back markets and the suppliers who are known in the front } \\
\text { markets. The organization always needs to collect } \\
\text { information about the customers to keep them and gain } \\
\text { their satisfaction and for the suppliers to ensure the } \\
\text { durability and continuity of the supply. }\end{array}$ & $\begin{array}{l}\text { Saida } \\
\text { - } 2019\end{array}$ \\
\hline Continuous process & $\begin{array}{l}\text { It is continuous process to search for strategic information } \\
\text { related to the environment in which the organization } \\
\text { operates, in order to capture positive and negative signals } \\
\text { (opportunities and threats) to direct the higher management } \\
\text { to take the necessary decisions to improve the } \\
\text { organization's performance and maintain its market share }\end{array}$ & \\
\hline
\end{tabular}

Through the previous definitions, it is necessary to define the procedural definition of the research that marketing vigilance is the continuous analysis of the marketing environment for the purpose of achieving a brilliant performance and building a good image and reputation for the company through the competitive marketing intelligence of company managers on how to invest the opportunities in the market.

\subsection{The importance of vigilance in marketing}

Many organizations are always based on the followed marketing strategies and their application, without looking and contemplating the changes that occur in the marketing environment constantly, which require continuous adaptation and adaptation with marketing events, in order to understand these changes and keep pace with them and take appropriate decisions in a timely manner.

Where the importance of marketing vigilance is highlighted through the following (AlQotji \& Mulla Hassan, 2019: 9):

- Contribute to assisting the top management in making the most of the advantages provided by the available marketing opportunities.

- Providing the organization with the necessary information on the development of customer requirements and desires.

- Assist the organization in building an important base of updated data on the marketing environment.

- It is considered an important indicator to enrich the strategic thinking of the marketing decision makers in the organization.

- It improves the mental image of the organization with the customers and shows a high sense of responsibility towards them.

\subsection{Objectives of vigilance marketing}

There are many goals that the marketing vigilance system achieves, as the marketing department in the organizations seeks to achieve them in order to succeed in their competitive performance and enhance their position in the markets, and the most prominent of these goals are (Dawood and Ibrahim, 2017: 51):

- Warning: By identifying threats and opportunities, identifying competitors 'trends and customers' trends. 
Marketing Vigilance and its Role in Ambidexterity Performance Applied Research in Baghdad Company for Soft Drinks

- Adaptation to the environment: by adjusting the company's resources to the expected changes, and here everything is related to expectation and decision-making.

- Action: interacting and innovating, solving problems that arise, and obtaining a competitive advantage.

- Types of vigilance marketing

There are several types of marketing vigilance as follows: - (Islam, 2017: 2)

- Technological surveillance: means anticipating and analyzing the technological environment with targeted dissemination of selected information and useful treatment in making strategic decisions. Information to decision-making centers.

- Commercial surveillance: the process of following up the development of the needs of the beneficiaries, as the library needs to take into account the interests and requests of the beneficiaries and the development of their relations with the library and its services. The commercial surveillance carries out continuous follow-up of the development of the needs of the beneficiaries and their ability to fulfill, and the extent of their ability to provide the scientific material.

- Competitive surveillance: This is a path that collects, analyzes and evaluates data on current and prospective competitors in a scientific and systematic manner, with the aim of providing useful information in re-competing strategies. Competitive surveillance is concerned with monitoring competitors' activities by gathering information necessary to understand their methods of providing services.

- Social surveillance: we mean the library's awareness of the various changes that may occur within the organization, as well as the analysis of social environment factors: such as an increase in the number of beneficiaries. The multiplicity and diversity of their specialties, and the requests of the beneficiaries (especially the requests for final years, in which the increasing demand is abundant).

\subsection{Dimensions of marketing vigilance}

\subsubsection{Monitoring and analyzing the marketing environment}

The marketing plan development process begins with an assessment of the situation and position facing the organization. The situation analysis identifies the strengths and weaknesses, as well as the opportunities and threats in the marketing environment. Based on the information obtained, the marketing objectives for specific products and markets are set and the marketing environment is a set of external forces and variables that affect the ability of the marketing department in organizations to build and maintain relationships with target customers (Kotler et al., 2017: 69). The marketing environment is to analyze all factors and changes affecting the internal and external environment in a comprehensive and objective manner, in order to build a model that can be adopted in the marketing analysis (AlSumaidaie and Al-Alaq, 2017: 51).

\subsubsection{Market acquired value}

The origin of the concept of value extends back to ancient times, as Aristotle dealt with it in economics, as he emphasized that a commodity has two values, the first of which is to use the purpose of which is to obtain a benefit and the second is substitution that arises from the exchange of goods for other commodities (Rabi'awi and Abbas, 2014: 183). The acquired market value is the customer's evaluation in general of the benefit of the product based on what was paid in exchange for the benefits received, and thus the value has two sides (Shubbr, 2014: 67): 
- From the customers' point of view, it represents (a low price, something that the customer wants in the product, the quality of the product reflects the price paid).

- From the point of view of the organization, it represents (understanding the needs and desires of consumers, attracting consumers by meeting those needs, building longterm relationships with customers).

\subsubsection{Marketing Competitive Intelligence}

It is a set of coordinated actions undertaken by the organization in searching for, collecting, analyzing and processing data to convert it into useful information provided to decisionmakers in the organization that is invested and exploited in order to achieve the goals of the organization and achieve a competitive advantage, and preserve it against risks and threats. In the surrounding environment. These procedures are carried out in ethical and legal ways (Leymarie, 2012: 15-16).

Marketing competitive intelligence is the best mechanism for the organization to follow through which the organization can obtain a competitive ability that distinguishes it from competitors, and it is exemplified by the following (Dufour, 2011: 65-66):

- Processing information through collecting, classifying, analyzing, processing and presenting decision-makers.

- Protecting and preserving this information by providing confidential and security systems for information related to material and intangible assets.

- The moral and legal framework in which this system operates, and its avoidance of espionage lends the competitive in Second: the skillful performance

As the topic deals with the concept of skilled performance, its importance, conditions for its success, its approaches, its characteristics, its strategies, and its dimensions, as follows:

\subsubsection{The concept of ambidextrous performance}

The origin of the word dexterity is derived from the Latin word ambos, which means "both hands", meaning the use of both hands in equal or multiple use (Karrer \& Fleck, 2013: 2). In the Oxford English Dictionary, dexterity means the ability of an individual to use both His hands are both equally ambidextrous (Nohman, 2015: 2), and ingenuity is one of the most important topics that aroused interest around researchers and organizations, as he acquired the concept of proficiency influential in scientific research as a basic ability to achieve the sustainable competitive advantage of organizations (Comez et al, 2011: 77). (Clercq et al, 2012: 5-6) believes that the term ingenuity refers to the ability to pursue two disparate things at the same time, such as (exploration and investment).

Table 3. The contributions of researchers in the field of defining ambidextrous performance for the period (2013-2020)

\begin{tabular}{|c|c|c|}
\hline Concentration & The definition & Researcher \\
\hline $\begin{array}{c}\text { Investing, exploration, } \\
\text { opportunities, risks } \\
\text { and experimentation }\end{array}$ & $\begin{array}{c}\text { The organization's ability to invest both } \\
\text { existing resources, improve what is } \\
\text { currently available to the organization, } \\
\text { and explore new opportunities through } \\
\text { risk and experimentation. }\end{array}$ & Wessel,2013:14 \\
\hline
\end{tabular}


Marketing Vigilance and its Role in Ambidexterity Performance Applied Research in Baghdad Company for Soft Drinks

\begin{tabular}{|c|c|c|}
\hline $\begin{array}{c}\text { Create value and explore } \\
\text { new opportunities }\end{array}$ & $\begin{array}{l}\text { The ability of the organization to manage } \\
\text { related activities by investing its current } \\
\text { capabilities in order to create value for } \\
\text { the organization in the short term, and to } \\
\text { explore new opportunities to ensure its } \\
\text { survival and continuity in the long term. }\end{array}$ & $\begin{array}{l}\text { Rashid and Jaber, } \\
\text { 2014: } 13\end{array}$ \\
\hline $\begin{array}{l}\text { Investing existing } \\
\text { products and } \\
\text { exploring a new } \\
\text { product }\end{array}$ & $\begin{array}{l}\text { An organization's ability to invest existing } \\
\text { products with known knowledge at the } \\
\text { same time, and explore a new product } \\
\text { with unfamiliar knowledge. }\end{array}$ & $\begin{array}{l}\text { Zaidi \& } \\
\qquad \text { Othman,2015:22 }\end{array}$ \\
\hline $\begin{array}{l}\text { Investing their current } \\
\text { capabilities and } \\
\text { exploring new } \\
\text { competencies }\end{array}$ & $\begin{array}{l}\text { The ability to invest their current capabilities } \\
\text { while exploring new competencies at the } \\
\text { same time. }\end{array}$ & Shoba,2017:16 \\
\hline $\begin{array}{l}\text { Investment and } \\
\text { exploration } \\
\text { capabilities in a } \\
\text { dynamic environment }\end{array}$ & $\begin{array}{l}\text { An organization's ability to maintain the dual } \\
\text { capabilities of both investing and } \\
\text { exploring to survive in dynamic } \\
\text { business environments and manage } \\
\text { organizational change.. }\end{array}$ & Roglinger et.al,2018:3 \\
\hline $\begin{array}{l}\text { Discover and invest in } \\
\text { new and existing } \\
\text { opportunities }\end{array}$ & $\begin{array}{l}\text { The organization's ability to pursue } \\
\text { exploration and investment and its } \\
\text { ability to invest current competencies } \\
\text { and explore new opportunities with its } \\
\text { ability to use and improve existing } \\
\text { knowledge }\end{array}$ & $\begin{array}{l}\text { Abdul-Jabbar: } 2020 \text {, } \\
111\end{array}$ \\
\hline
\end{tabular}

Through the previous definitions, it is necessary to define the procedural definition of the research that the ambidextrous performance is the ability of the company to seize and discover the opportunities that exist to achieve the goals of the company, and it is effective, efficient and creative performance.

\subsubsection{The importance of clever performance}

Good performance is linked to long-term success as it seeks to strike a balance between exploration and investment simultaneously. The scientific literature has identified the importance of ambidextrous performance as follows:

- The ambidextrous performance is important in the management's practice of its business, taking into account the characteristics of the competitive environment in which the organizations operate, and the need for both exploration and investment. (Ortego \& Azorin, 2018: 85) 
- And (Hussein and Al-Ani, 2018: 279) pointed out another importance of ambidextrous performance: -

- The importance of ambidextrous performance appears in enabling business organizations to diversify their ambidextrous, as it combines current opportunities and future visions in an environment characterized by a high degree of uncertainty and the need for rapid development and ability to shift towards opportunities, which is one of the conditions for success.

- The importance of ambidextrous performance in the field of projects appears widely in the field of the public and private sectors as a means of introducing new products, commercial benefits or organizational change, and this has led to the expansion of the scope of work methods and has become an approach for many organizations.

- Ambidextrous performance as a strategic goal represents the desired goals that are achieved through appropriate means or organizational learning processes (Sulphey \& Allkahtani, 2017: 336).

\subsubsection{Conditions for successful performance}

(O'Reilly \& Tushman, 2011: 9) and (Ibrahim, 2017: 212) suggested that there are conditions for the success of organizations characterized by good performance as follows: -

- Clarity of the important strategic goal that appears intellectually as both exploration and investment.

- Knowing the common identity by clarifying the common vision and values across the exploration and investment units.

- The ambidextrous team's possession of clear and balanced exploratory and investment strategic units that occur in the external environment.

- Effective performance entries

Structural prowess: Structural prowess is called (architectural prowess) is a model in which exploration and investment are divided into different structures or sub-units, and this model is often applied in large organizations (Boukamel \& Emery, 2017: 5), is a design or organizational form that does not contain Only on separate sub-units for exploration and investment, but also different specializations, systems, incentives, processes and cultures for each unit (Schudy, 2010: 6). The basic principle of this approach is the creation of separate structural units that are independent of each other, and each of them seeks either exploration or investment (Nohman, 2015: 23).

Contextual ambidextrous: as the behavioral ability to show alignment and adaptability simultaneously across the entire business unit, and this type of ingenuity depends on the systems, incentives and processes that shape individual behaviors in the organization (Brion et.al, 2010: 4). To the Toyota production system, where workers perform routine tasks such as assembling cars (investment), but they are expected to constantly change jobs to become more efficient (exploration) (Nohman, 2015: 24), and include contextual factors that affect individuals' behavior, incentive systems, and vision. The joint, balance of discipline, support, confidence and extensibility (Klinger, 2016: 23).

Sequential ambidextrous: Sequential ingenuity is considered as a category of adept performance because the concept of ingenuity depends on effective organizational ability to manage investment and exploration simultaneously, and sequential ingenuity indicates (by cross-balance) in which periods of investment and periods of exploration succeed (Boukamel \& Emery, 2017: 7) ), Which is the ability of the organization to change and build its structures which, by organizing its structures, can reflect changing environmental conditions or strategies. Sequential ingenuity is more appropriate in stable environments, and it is generally 
Marketing Vigilance and its Role in Ambidexterity Performance Applied Research in Baghdad Company for Soft Drinks

more beneficial for small organizations that lack the resources to apply sequential ingenuity (Nohman, 2015). : 22).

\subsubsection{Strategies for ambidextrous performance}

The strategy is the ambidextrous performance is a high ability to follow with the exploration and investment strategies of products, market and resources, so organizations must respond effectively to the current markets and at the same time prepare for the new market by practicing the strategy of skilled performance (Musigire et al, 2017: 77), Mashahadi (et al, 2015: 146) defines the ambidextrous performance strategy as simultaneous actions by organizations between heterogeneous things.

(Comez et al., 2011: 78) Popadic et al. (2016: 296-297) explain the strategies of ambidextrous performance as follows:

Exploratory innovation strategy: The ability to deal with changing environments, open new business opportunities, and thus produce new products to meet customer needs, create new markets, and include high levels of uncertainty, and implement the exploratory strategy by the research and development department, aiming to enter areas New product markets.

Investment innovation strategy: Creates value by strengthening organizations' existing knowledge base, improving existing products or processes, and is a low-risk strategy that prevents positive returns., And aims to improve the current product market position.

\subsubsection{Dimensions of ambidextrous}

Exploring opportunities: the extent to which the organization is able and willing to use its scarce resources, skills and abilities to identify the marketing opportunities available in the foreign market before other competitors discover them, including research processes, difference, risks, flexibility, experimentation, innovation (construction, 2016: 235), Exploration is linked to several activities, including research, difference, risk, flexibility, experimentation, radical innovation, diversity and the creation of new products, processes and services, and it is also linked with entrepreneurship, improvisation, chaos, and the emergence of markets and technologies (Armor, 2015: 5) (Kalgovas et al, 2014: 3) The exploration of opportunities by individuals is through their search for opportunities to improve current processes or technology, products, services and work relationships, and the extent to which they distinguish opportunities for making positive improvements in their work or units or even with the organization's customers (Mezher, 2017: 10).

Investing opportunities: the organization's endeavor towards investing external marketing opportunities to achieve its goals and monitor the customer's needs as opportunities that contribute to improving the level of sales and increasing market share, including processes of improvement, selection, efficiency, production, implementation, refinement (Andersen et al, 2017: 135). Investing opportunities also in mechanical and mechanical structures, structures and routine, and reliance on pathways, bureaucracy, and stable markets (Sulphey \& Allkahtani, 2017: 337).

Centralization: It is the third dimension of the dimensions of skilled performance, and it is an element of the independence of delegating the characteristic of the organized authority and the degree to which the decision-making unit is stationed at the higher levels of the organization, for example the board of directors or the executive director related to the role of formal authority and hierarchical mechanisms in decision-making processes (Martens et.al, 2017: 5 (Shoghi, 2013: 92).

\section{THE PRACTICAL SIDE}




\subsection{Description and analysis of checklist results}

A detailed explanation of the main and sub-variables of the research will be made. The focus of the research is to display the results of the answers to the checklist questions, and to analyze the data to reach the results of the research based on a statistical method (descriptive analysis) by extracting the occurrences, arithmetic means, and percentages of the extent to which the sub-variables match the reality of a company. Al-Zawraa in question, and the size of the gap, through the answers to the three-scale checklist (fully achieved, verified, unfulfilled) and the corresponding weights $(1,2,3)$ respectively, so that the average of the scale approved for comparison is equal to (2) That is, partially achieved, and as explained later.

And through field coexistence and personal interviews for most of the departments, divisions, and units in the company in question, and seeing the nature of their respective businesses, an intentional sample was taken, represented by a department manager and an experienced division in the research community, for the purpose of obtaining realistic answers to fill out the checklist Where the contents of the questions on the checklist were explained to clarify its paragraphs, and I intended these contents again after about a month by directing indirect questions and inquiries related to the same list without reference to them to ensure the realism of the answers, until the checklist came out with final answers that correspond to reality, and what follows: Analysis of checklist results:

\subsubsection{Marketing vigilance}

A continuous and continuous process of searching for strategic, social, political and technological information on the environment in which the organization operates in order to capture positive and negative signals) opportunities and threats to direct the top management of the organization towards achieving outstanding performance.

In measuring the independent variable (marketing vigilance), the researcher relied on seven dimensions: monitoring and analyzing the marketing environment, proactive information for expected marketing problems, investment of marketing opportunities, acquired market value, a product image, normalization of the relationship with risk, and competitive marketing intelligence) to know the extent of its awareness Regarding the sample responding to this variable, it has a total amount of ... paragraphs (35) poverty, and the following is an explanation of the dimensions of marketing vigilance according to the checklist.

Monitoring and analyzing the marketing environment: The organization monitors and controls the environment in which it operates through data collection, analysis and processing, and diagnosing strengths, weaknesses, opportunities and threats.

Table ().results show that "monitoring and analyzing the marketing environment" obtained a rate of (2.2), that is, partially achieved, and that the percentage of the extent of conformity is $(73.3 \%)$ and the size of the gap is $(26.7 \%)$, which is a high percentage for the soft drink company, so it could be Monitoring and analyzing the marketing environment in terms of competing products and customers' tastes and needs, especially as we now live under inappropriate health conditions (Covid 19 pandemic) that require the company to restructure the electronic administrative work, especially in the distribution process, and conduct a survey on the needs and desires of customers as well as collect Information about the economic, political, social and marketing environment, and that the company has a marketing vigilance that can collect high-precision information ... through extranet or intranet between departments or the company and the rest of other institutions.

Calculations were performed in the following manner: (Al-Khatib, 2008: 349), (AlShammari, 2013: 173 
Marketing Vigilance and its Role in Ambidexterity Performance Applied Research in Baghdad Company for Soft Drinks

Weighted arithmetic mean $=(($ Frequency $\mathrm{x}$ Weight $)$ total $) /($ Repetitions total $=($ $\frac{(0 * 1)+(4 * 2)+(1 * 3)}{0+4+1}=\frac{11}{5} 2.2=$

Percentage Match Range $=($ Mean Weighted $) /($ Scale in Higher Score (

$=\frac{2.2}{3} \% 73.3=$

Gap Size $=1-$ match extent percentage

$\% 26.7=(\% 73.3-1)=$

Table 4.shows the checklist to monitor and analyze the marketing environment

\begin{tabular}{|l|l|l|l|}
\hline The paragraphs & Unrealized & $\begin{array}{l}\text { Partially } \\
\text { verified }\end{array}$ & $\begin{array}{l}\text { Fully } \\
\text { verified }\end{array}$ \\
\hline $\begin{array}{l}\text { The company's management monitors the markets in which its } \\
\text { products are offered ... }\end{array}$ & & & $*$ \\
\hline $\begin{array}{l}\text { The company's management conducts a comparison with other } \\
\text { competing companies to improve its position in the market. }\end{array}$ & & $*$ & \\
\hline $\begin{array}{l}\text { The company's management strengthens its competitive position } \\
\text { in the markets by analyzing problems in the marketing } \\
\text { environment to address them }\end{array}$ & * & \\
\hline $\begin{array}{l}\text { The company's management monitors the opportunities available } \\
\text { in the marketing environment to increase the volume of its sales. }\end{array}$ & & $*$ & \\
\hline $\begin{array}{l}\text { The process of monitoring and controlling the marketing } \\
\text { environment contributes to supporting the company's management } \\
\text { in making decisions. }\end{array}$ & 1 & $*$ & \\
\hline Weights & 0 & 4 & 1 \\
\hline Duplicates & 0 & 8 & 3 \\
\hline The result & 2 & & \\
\hline The weighted arithmetic mean & 66.7 & & \\
\hline Match extent percentage & 33.3 & & \\
\hline The size of the gap & & & \\
\hline
\end{tabular}

Proactive information for expected marketing problems: The Company's management collects information in advance through continuous monitoring and monitoring of the environment in which it operates in order to face the expected marketing changes and problems.

Table.5. results show that "anticipatory information for expected marketing problems" obtained a weighted arithmetic mean (2.33), which is a high tendency for the research sample, which is close to fully verified, and that the percentage of matchmaking is $(77.7 \% 7)$ and the gap size is $(22.22 \%)$ It is a small percentage, but it needs to be reviewed by the soft drink company. The company tends to improve its ability to disclose information as quickly as possible by being alert to the marketing environment. The company's management also focuses on proactive information that helps it act in a timely manner in addition to gathering management The Company provides information on developments in the field of scientific research when developing its products.

Table 5. The checklist shows the proactive information for the expected marketing problems

\section{Proactive information for anticipated marketing issues}




\begin{tabular}{|l|l|l|l|}
\hline The paragraphs & Unrealized & $\begin{array}{l}\text { Partially } \\
\text { verified }\end{array}$ & $\begin{array}{l}\text { Fully } \\
\text { verified }\end{array}$ \\
\hline $\begin{array}{l}\text { The company's management improves its ability to reveal } \\
\text { information as quickly as possible by being alert to the marketing } \\
\text { environment. }\end{array}$ & & & $*$ \\
\hline $\begin{array}{l}\text { The company's management has proactive information that helps } \\
\text { it act in a timely manner. }\end{array}$ & & $*$ & $*$ \\
\hline $\begin{array}{l}\text { The company's management carefully monitors competitors } \\
\text { 'movements in the market and works to collect proactive } \\
\text { information before competitors. }\end{array}$ & $*$ & \\
\hline $\begin{array}{l}\text { The company's management benefits from the results of its } \\
\text { proactive marketing forecasts in solving the expected marketing } \\
\text { problems. }\end{array}$ & & & \\
\hline $\begin{array}{l}\text { The company's management collects information on } \\
\text { developments in the field of scientific research when developing } \\
\text { its products. }\end{array}$ & & & $*$ \\
\hline Weights & 1 & 2 & 3 \\
\hline Duplicates & 0 & 2 & 3 \\
\hline The result & 1 & 4 & 9 \\
\hline The weighted arithmetic mean & 2.33 & & \\
\hline Match extent percentage & 77.77 & & \\
\hline The size of the gap & 22.22 & & \\
\hline
\end{tabular}

Earned value: It is the process of exchange by customers between the quantitative benefit from the use of products (reputation, service) and the quantitative costs that were spent in order to obtain the product.

As the results of Table (6) show that the "earned value" dimension has obtained a weighted arithmetic mean (2.6) that is partially achieved and that the percentage of the extent of conformity is $(86.66 \%)$ and the size of the gap is $(13.33 \%)$, which is a high percentage for the company. Addressing deficiencies ... According to this dimension, the company's management seeks to deal with different segments that add to me a high social and cultural value. The company's management has a high capacity to satisfy its needs and desires. The company's management has the ability to provide distinguished services with products to gain the loyalty of customers.

Table 6. Shows the checklist for the earned value dimension

\begin{tabular}{|c|c|c|c|}
\hline \multicolumn{4}{|l|}{ Earned value } \\
\hline The paragraphs & Unrealized & $\begin{array}{c}\text { Partially } \\
\text { verified }\end{array}$ & $\begin{array}{l}\text { Fully } \\
\text { verified }\end{array}$ \\
\hline $\begin{array}{l}\text { The company's management deals with different segments that } \\
\text { add to me a high social and cultural value }\end{array}$ & & & $*$ \\
\hline $\begin{array}{l}\text { The company's management possesses a high ability to satisfy } \\
\text { his needs and desires }\end{array}$ & & & $*$ \\
\hline $\begin{array}{l}\text { The company's management has the ability to provide } \\
\text { distinguished services with products to gain customer loyalty. }\end{array}$ & & & $*$ \\
\hline
\end{tabular}


Marketing Vigilance and its Role in Ambidexterity Performance Applied Research in Baghdad Company for Soft Drinks

\begin{tabular}{|l|l|l|l|}
\hline $\begin{array}{l}\text { The company's management works to build long-term } \\
\text { relationships with customers }\end{array}$ & & $*$ & \\
\hline $\begin{array}{l}\text { The company's products generally provide a kind of guarantee } \\
\text { and safety for customers. }\end{array}$ & & $*$ & \\
\hline Weights & 1 & 2 & 3 \\
\hline Duplicates & 0 & 2 & 3 \\
\hline The result & 0 & 4 & 9 \\
\hline The weighted arithmetic mean & 2.6 & & \\
\hline Match extent percentage & 66.86 & \\
\hline The size of the gap & 33.13 & \\
\hline
\end{tabular}

The mental image of the product: It is the position and impression that the company's products (reputation, service) leave in the minds of customers and through which they gain their satisfaction and loyalty. As the results of Table.7. Show that the "mental image of the product" obtained a weighted arithmetic mean (1.6) that is close to partially achieved, that the percentage of the extent of conformity is $(53 \%)$ and that the size of the gap is $(47 \%)$, which is a high percentage for the company. The availability of technical and financial resources contributes to an efficient investment as there is cooperation, coordination and mutual benefits between the parties, especially the departments in the company, in order to serve the customer and build a good mental image of the product.

Table 7. The checklist shows the mental image of the product

\begin{tabular}{|l|l|l|l|}
\hline The mental image of the product & Unrealized & $\begin{array}{l}\text { Partially } \\
\text { verified }\end{array}$ & $\begin{array}{l}\text { Fully } \\
\text { verified }\end{array}$ \\
\hline The paragraphs & & $*$ & \\
\hline The company's products are the customer's first choice & $*$ & \\
\hline $\begin{array}{l}\text { The customer has high confidence in the company's management } \\
\text { and deals with them very seriously. }\end{array}$ & & $*$ & \\
\hline $\begin{array}{l}\text { I will continue to deal with the company's products in the coming } \\
\text { years }\end{array}$ & & $*$ & \\
\hline $\begin{array}{l}\text { There is a high inclination of customers on the company's } \\
\text { products }\end{array}$ & & & \\
\hline $\begin{array}{l}\text { The customer is fully convinced that the company management } \\
\text { will not deceive and let him down. }\end{array}$ & $*$ & 2 & 3 \\
\hline Weights & 1 & 3 & 0 \\
\hline Duplicates & 2 & 6 & 0 \\
\hline The result & 2 & \\
\hline The weighted arithmetic mean & 1.6 & \\
\hline Match extent percentage & 0.53 & \\
\hline The size of the gap & 0.47 & \\
\hline
\end{tabular}

Marketing Competitive Intelligence: It is a program that aims to collect information about competitors. The company uses these programs to collect, analyze and interpret information about competitors, on which the company's management depends on decision-making and strategic development.

As the results of Table 8 show that the "marketing competitive intelligence" obtained a weighted arithmetic mean (1.8), i.e. close to partially achieved, and that the percentage of the extent of conformity is $(60 \%)$ and that the size of the gap is $(40 \%)$, which is a high percentage for the company, as The company must know the future demand for its products as well as the 
demand direction for these products in the current and new markets, in addition to that the company needs to know its competitors in the market and the most accurate details in order to be able to build a strategy to penetrate the markets and build a good market share.

Table 8. shows the checklist for Marketing Competitive Intelligence

\begin{tabular}{|l|l|l|l|}
\hline Marketing Competitive Intelligence & Unrealized & $\begin{array}{l}\text { Partially } \\
\text { verified }\end{array}$ & $\begin{array}{l}\text { Fully } \\
\text { verified }\end{array}$ \\
\hline The paragraphs & $*$ & $*$ & \\
\hline $\begin{array}{l}\text { The company's management has the necessary information about the future } \\
\text { demand for its products }\end{array}$ & & \\
\hline $\begin{array}{l}\text { The company's management has full knowledge of the demand trends for its } \\
\text { current products in the target markets. }\end{array}$ & & $*$ & \\
\hline $\begin{array}{l}\text { The company's management has the ability to know its current and potential } \\
\text { competitors to see their moves in the future }\end{array}$ & & $*$ & \\
\hline $\begin{array}{l}\text { The company's management has the ability to recognize its competitive position } \\
\text { in the market }\end{array}$ & & $*$ & \\
\hline $\begin{array}{l}\text { Company management responds quickly to the requirements and needs } \\
\text { of customers }\end{array}$ & & 2 & 3 \\
\hline Weights & 1 & 4 & 0 \\
\hline Duplicates & 1 & 8 & 0 \\
\hline The result & 1 & \\
\hline The weighted arithmetic mean & 1.8 & \\
\hline Match extent percentage & 0.60 & \\
\hline The size of the gap & 0.40 & & \\
\hline
\end{tabular}

\subsubsection{Ambidextrous performance}

The organization's ability to seek to explore and invest in it, and its ability to invest existing competencies, explore new opportunities and improve existing knowledge.

Exploring opportunities: The extent of the organization's ability and desire to use its resources, skills and capabilities to identify the marketing opportunities available in the business environment before being discovered by other competitors.

The results of Table .9 show that "exploring opportunities" obtained a weighted arithmetic mean (2.6), i.e. close to fully achieved, and that the percentage of the extent of conformity is $(86.7 \%)$ and that the size of the gap is $(13.3 \%)$, which is a small percentage for soft drinks, as The management of the company seeks to find new business opportunities in the market ... It also contributes to satisfying the interests of the rest of the other parties as there is cooperation, coordination and mutual benefits between the departments and the higher management as well as the company has a great ability to improve the current market opportunities, in addition to the company has a great capacity To improve the current market opportunities.

Table 9.Checklist for exploring opportunities

\begin{tabular}{|l|c|c|c|}
\hline \multicolumn{1}{|c|}{ The paragraphs } & Unrealized & $\begin{array}{c}\text { Partially } \\
\text { verified }\end{array}$ & $\begin{array}{c}\text { Fully } \\
\text { verified }\end{array}$ \\
\hline $\begin{array}{l}\text { The company's management seeks to find new business } \\
\text { opportunities in the market. }\end{array}$ & & & $*$ \\
\hline
\end{tabular}


Marketing Vigilance and its Role in Ambidexterity Performance Applied Research in Baghdad Company for Soft Drinks

\begin{tabular}{|l|l|l|l|}
\hline $\begin{array}{l}\text { The company's success depends on its ability to discover new } \\
\text { technologies at work. }\end{array}$ & & * & \\
\hline $\begin{array}{l}\text { The company has a great ability to improve the current market } \\
\text { opportunities. }\end{array}$ & & & $*$ \\
\hline $\begin{array}{l}\text { The company is committed to introducing new technological } \\
\text { fields. }\end{array}$ & & & $*$ \\
\hline Weights & 1 & 2 & 3 \\
\hline Duplicates & 0 & 1 & 3 \\
\hline The result & 0 & 2 & 9 \\
\hline The weighted arithmetic mean & 2.75 & & \\
\hline Match extent percentage & .92 & \\
\hline The size of the gap & .8 & \\
\hline
\end{tabular}

exploration opportunities: The company's endeavor towards investing marketing opportunities in the business environment and meeting the customer's needs as opportunities that contribute to improving sales and increasing market share, and then achieving the company's goals.

There are many establishments, restaurants, clubs and markets that deal with the research sample company in the Iraqi market. The results of Table 10 show that after "investing opportunities", a weighted arithmetic mean (2.5) was obtained, meaning more than partially achieved, and that the percentage of the extent of conformity is $(83 \%)$ and the size of the gap is $(17 \%)$, which is a high percentage for the soft drink company. The deficiency must be addressed ... Therefore, according to this dimension, the company tries to convince the parties dealing with it of the need to cooperate with it in the field of distribution and supply of materials.

Table. 10. Checklist for exploration opportunities

\begin{tabular}{|l|l|l|l|}
\hline \multicolumn{1}{|c|}{ The paragraphs } & Unrealized & $\begin{array}{c}\text { Partially } \\
\text { verified }\end{array}$ & $\begin{array}{c}\text { Fully } \\
\text { verified }\end{array}$ \\
\hline $\begin{array}{l}\text { The company is increasing economies of scale in existing } \\
\text { markets through its ability to absorb the increase in market } \\
\text { demand. }\end{array}$ & & & $*$ \\
\hline The company seeks to expand its existing skills and knowledge. & & $*$ & \\
\hline $\begin{array}{l}\text { The company is interested in meeting the needs of the current } \\
\text { customers more than the potential ones. }\end{array}$ & & $*$ & \\
\hline $\begin{array}{l}\text { The company has the ability to improve its activities to generate } \\
\text { value in the short term }\end{array}$ & & & $*$ \\
\hline Weights & 1 & 2 & 3 \\
\hline Duplicates & 0 & 2 & 2 \\
\hline The result & 0 & 4 & 6 \\
\hline The weighted arithmetic mean & 2.5 & & \\
\hline Match extent percentage & 0.83 & & \\
\hline The size of the gap & 0.17 & & \\
\hline
\end{tabular}

Effectiveness: It refers to the level of success achieved by management towards achieving the goal. The closer the administration is to achieving its goals, the more effective managers will be. 
The results of Table 11.show that the "dimension of activity" has obtained a weighted arithmetic mean (2.75), which is close to fully achieved, and that the percentage of the extent of conformity is (92\%) and that the size of the gap is $(8 \%)$, which is a small percentage for the company while it is operating properly. Large for the local market, so the company's management is interested in providing techniques that have an impact on the effectiveness of operations within the company. The company's management can also achieve its goals within the time set for it. This indicates the degree of satisfaction of the employees in the researched company. This indicates that the company's policies are characterized by the care of employee's at all organizational levels. The employees also feel that they are joining forces to improve the company's performance levels. Therefore, job satisfaction is one of the basic factors that affect job performance, as job dissatisfaction or its decrease leads to poor performance and lower productivity, which leads to inactivity.

Table 11. Shows the checklist Effectiveness

\begin{tabular}{|l|l|l|l|}
\hline \multicolumn{1}{|c|}{ The paragraphs } & Unrealized & $\begin{array}{c}\text { Partially } \\
\text { verified }\end{array}$ & $\begin{array}{c}\text { Fully } \\
\text { verified }\end{array}$ \\
\hline $\begin{array}{l}\text { The company's management is interested in providing technologies that } \\
\text { have an impact on the effectiveness of operations within the company. }\end{array}$ & & $*$ & $*$ \\
\hline The company's management is keen to achieve the goals set accurately. & & & \\
\hline $\begin{array}{l}\text { The company uses modern technologies to achieve excellence in } \\
\text { performance. }\end{array}$ & & & $*$ \\
\hline $\begin{array}{l}\text { The management of the company cannot achieve its goals within the } \\
\text { specified time. }\end{array}$ & & & $*$ \\
\hline Weights & 1 & 2 & 3 \\
\hline Duplicates & 0 & 1 & 3 \\
\hline The result & 0 & 2 & 9 \\
\hline The weighted arithmetic mean & 2.75 & & \\
\hline Match extent percentage & .92 & \\
\hline The size of the gap & .8 & \\
\hline
\end{tabular}

Efficiency: it is doing the right things in a correct way, so effectiveness is related to leadership, while efficiency is related to management. Therefore, the results of Table12 show that "efficiency" got a rate of (2.6), meaning between partially achieved to fully achieved and that the percentage of the extent of conformity is $(86.6 \%)$ and the size of the gap is $(13.33 \%)$, which is a high percentage for the soft drink company, despite Therefore, the deficiencies must be addressed, so the company must work continuously to evaluate the plans and activities implemented to identify deviations. The company also monitors the performance of its employees and management and relies on results as military feeding to develop its inputs. In addition, work reports and completion rates are followed up by the top management of the researched company, depending on the amount of inputs.

Table 12. Shows the checklist Effectiveness

\begin{tabular}{|l|l|l|l|}
\hline The paragraphs & Unrealized & $\begin{array}{c}\text { Partially } \\
\text { verified }\end{array}$ & $\begin{array}{l}\text { Fully } \\
\text { verified }\end{array}$ \\
\hline The total revenues of the company increased during the last three years. & & $*$ & \\
\hline $\begin{array}{l}\text { The company works continuously to evaluate the implemented plans } \\
\text { and activities to identify deviations. }\end{array}$ & & $*$ & \\
\hline $\begin{array}{l}\text { The company monitors the performance of its employees and adopts the } \\
\text { results as military nutrition to develop its inputs. }\end{array}$ & & & $*$ \\
\hline $\begin{array}{l}\text { The work reports and completion rates are followed up by the } \\
\text { company's senior management. }\end{array}$ & & & $*$ \\
\hline Weights & 1 & 2 & 3 \\
\hline
\end{tabular}


Marketing Vigilance and its Role in Ambidexterity Performance Applied Research in Baghdad Company for Soft Drinks

\begin{tabular}{|l|l|l|l|}
\hline Duplicates & 0 & 2 & 2 \\
\hline The result & 0 & 4 & 6 \\
\hline The weighted arithmetic mean & 2.6 & \\
\hline Match extent percentage & 86.7 \\
\hline The size of the gap & 13.3 & \\
\hline
\end{tabular}

Creative performance: the ability of the individual to generate new and useful ideas in relation to procedures and processes at work, as well as referring to the development of a new product, idea, or problem solution that serves as a basis for creativity by individuals, organizations and society.

Table 13 results show that the "creative performance" got a rate of (2.5), meaning between partially achieved to fully achieved, and that the percentage of the extent of conformity is $(83.3 \%)$ and the size of the gap is $(16.7 \%)$, which is a high percentage for the company. Addressing deficiencies, through an appropriate and effective strategy in some departments and the company's people, and the performance of employees is characterized by seriousness and the ability to assume responsibility. Positive creativity among employees, which in turn increases the productivity of work within the company, and the table below shows the results of the creative performance checklist.

Table 13. A checklist for the creative performance dimension

\begin{tabular}{|l|l|l|l|}
\hline \multicolumn{1}{|c|}{ The paragraphs } & Unrealized & $\begin{array}{c}\text { Partially } \\
\text { verified }\end{array}$ & $\begin{array}{c}\text { Fully } \\
\text { verified }\end{array}$ \\
\hline $\begin{array}{l}\text { The employees are brave enough to take on creative, previously unused } \\
\text { jobs. }\end{array}$ & & $*$ & \\
\hline $\begin{array}{l}\text { The performance of the employees is characterized by seriousness and } \\
\text { the ability to assume responsibility. }\end{array}$ & & & $*$ \\
\hline $\begin{array}{l}\text { The organization adopts a policy of motivating employees by rewarding } \\
\text { the outstanding performance of working individuals. }\end{array}$ & & $*$ & \\
\hline People take risks in implementing new creative methods. & & & $*$ \\
\hline Weights & 1 & 2 & 3 \\
\hline Duplicates & 0 & 2 & 2 \\
\hline The result & 0 & 4 & 6 \\
\hline The weighted arithmetic mean & 2.5 & & \\
\hline Match extent percentage & 83.3 & & \\
\hline The size of the gap & 16.7 & \\
\hline
\end{tabular}

\section{CONCLUSION}

- It appears that there is a very big gap in the mental image of the soft drink company's products, and this indicates the weakness of the promotional and advertising programs of the company in question.

- The company does not have vigilance with marketing intelligence for its products, as it lacks a high-precision plan to promote its products and to build long-term scenarios to clarify the future of the company in question.

- The strategic analysis of the environment of the company is very necessary to define and formulate its strategic plans, but there is a weakness in its analysis of the environment, and this may be due to the turmoil and complexity of the Iraqi market.

- There are few initiatives for the company, especially that the company does not have the competence to anticipate future events, and for which a database and proactive 
information about its local markets must be available for the purpose of activation and increase its production for the purpose of expansion and increasing production capacity.

- There are multiple segments of the society wanting in the products of the company being researched. They also have long-term relationships with the company and its products, but they need more maintenance of these segments as well as gain and attract the largest number of customers to increase its market share.

\section{RECOMMENDATIONS}

- Processing and correcting the mental image of the company's products through advertising and promotion means to display the characteristics of the existence of its products. Likewise, it is necessary to promote the local product.

- The necessity of employing market research as well as an environmental survey for the sake of environmental alertness around the perimeter of the company from variables or factors that may affect the work of the company as well as the leaders of the company must be able to use their intelligence in developing the company's work by identifying the most important dimensions of intelligence that can be invested to achieve advantage Pioneer for the searched company.

- Promote and support studies that the company may benefit from in order to know its strengths to enhance it, to know its weaknesses, and to deal with them, as well as how to invest the opportunities in its marketing environment and face the challenges that may be from other competitors.

- Consolidating the relationship with suppliers and existing customers and trying to attract new customers for their products by searching for new markets.

- Building a database that contributes to taking the pioneering decision of the company's leaders, as well as providing information systems that help in providing proactive information before competitors about customers, markets or competitors.

\section{REFERENCES}

[1] Ibrahim, Maha Sabah (2017), "Organizational Prowess and Its Impact on Achieving Strategic Success - An Applied Study in the National Islamic Bank", Journal of Accounting and Financial Studies, Volume 12, Issue 39, pp. 204-230.

[2] Construction, Zainab Makki Mahmoud (2016), "The Role of Organizational Prowess in Building Educated Organizations Through Radical Creativity", Karbala University Scientific Journal, Volume 14, Issue 2, pp. 228-256.

[3] Khanfas, Ahmad Hussein: 2020 "The Role of Marketing Vigilance in Internal Marketing According to the KANO Model Applied Research in Al-Zawraa State Company, Master Thesis, Department of Industrial Management, College of Administration and Economics.

[4] Daoud, Fadila Salman and Ibrahim, Hussein Ali: 2017, "Strategic Vigilance and its Role in Improving the Level of Nursing Services / Applied Research at Ghazi Hariri Hospital", Journal of Economic and Administrative Sciences, Volume 13, No. 96.

[5] Al-Rabiaoui, Saadoun Hamoud Jotheer and Abbas, Hussein Walid Hussein: 2012, "Marketing is a contemporary approach", Ghaidaa House for Publishing and Distribution, Baghdad. 
Marketing Vigilance and its Role in Ambidexterity Performance Applied Research in Baghdad Company for Soft Drinks

[6] Rashid, Saleh Abdul Redha and Jaber, Dr. Najah (2014), "The Role of Behavioral Integration of the Senior Management Team in Achieving Contextual Excellence", Al-Qadisiyah Journal of Administrative and Economic Sciences, Volume 16, No. 4, pp. 6-32.

[7] Abdul-Jabbar, Zeina Faiq: 2020 "Skillful Performance According to Entrepreneurial Marketing" Comparative study between PepsiCo and Sinalco Soft Drinks, Master Thesis, Department of Industrial Management, College of Administration and Economics.

[8] Al-Qotji, Bashar Zakir Salih: 2012, “Alignment between Strategic Vigilance and Marketing Opportunities to Select Competitive Marketing Strategies - A Comparative Study of Khulwah Telecommunication Companies in the City of Mosul", $\mathrm{PhD}$ thesis in Business Administration, College of Administration and Economics / University of Mosul.

[9] Yamina, Hawassi: 2017, "Marketing vigilance and its role in economic development in light of information and communication technology", Journal of Economics and Development, Medea University / Algeria, Issue 7.

[10] Miaux, Jean-François (2011), —Mise en œuvre d'une activité de veille : le cas de Réseau Ferré de Francell, Memoire pour obtenir le Titre professionnel "Chef de projet en ingénierie documentaire" INTD niveau I, CONSERVATOIRE NATIONAL DES ARTS ET METIERS.

[11] Muniz, Raquel Janissek \& Becker, Fábio Dídimo \& Lesca, Humbert \& Freitas, Henrique (2017), - L'usage de la Veille Anticipative Stratégique pour le suivi de la Bourse: le cas brésilienGrendeneS/All,ResearchGate,https://www.researchgate.net/publication/312580Blanc, Livre (2013), - La Veille Du concept à la réalité, culture, method, outils\|, Agentielle cabinet de veille, www.agentielle.com. 664.

[12] AI-Shawabkeh, Khaled Mahomoud :2018, " Exploring the Mediating Role of Knowledge Sharing between Human Resource Development and Organizational Ambidextrity" , European Joural of Scientific Research, Vol.149, No.3, pp.345-361 .

[13] Andersen, Peter \& Svejvig, Per \& T.Heeager, Lise :2017, "Ambidextritrous IT Governance :The Art of Balancing Exploration and Exploitation in IT Governance" , Association for Information systems AIS Electronic Library, pp.134-146 .

[14] Armour, Alexandro F. : 2015 , " Achieving Contextual Ambidexterity Through the Implementation of High Performance Work Systems (HPWS) " , The Degree Executive Doctorate in Business, The Robinson College of Business, Georgia State University .

[15] Brion, Sebastien \& Mothe, Caroline \& Sabatier, Mareva :2010, " The impact of organizational context and competences on innovation ambidexterity" , International Journal of Innovation Management, pp.151-178 .

[16] Dawood, Fadhiela Salman \& Abbas, Ali Fakhri (2018), - The Role of Strategic Vigilance in the Operational Performance of the Banking Sector: Field Research in a Sample of Private Banksll, European Journal of Business and Management, Vol.(10), No.(21).

[17] Dufour, Fanny (2011), —Approche dynamique de l'intelligence économique enentreprise : apports d'un modèle psychologique des compétences : Contribution à 1_élaboration de programmes d_actions de la CCI de Rennesll, Thèse présentée sous le sceau de 1,Université européenne de Bretagne En vue de 1,obtention du grade de Docteur en Psychologie", Laboratoire Armoricain Universitaire de Recherche en Psychologie Sociale

[18] Gomez, Luis (2015), -Comment se préserver de l'intelligence économique de la concurrence?\|, Memoire De Recherche Bachelor of Business, Ecole De Commerce De Lyon. 
[19] Kotler, Philp \& Armstrong, Gary \& Harris, Lloyd C. \& Piercy, Nigel (2017), Principles of Marketing\|, ed, Pearson Education Limited.

[20] Leymarie, Anna (2012), "La diffusion des résultats de la veille : enjeux, methods et pratiques. Le cas de 1'Institut National de 1'Environnement Industriel et des Risques (INERIS)" HAL(Humanities and Social Sciences), https://memsic.ccsd.cnrs.fr/mem_00679852

[21] Martens, Cristina Dai Pra: 2017, " Entrepreneurial Orientation in Food Industries: Exploratory study on Medium and Large size companies in south of Brazil" , international Conference Entrepreneurial in BRICS , pp.1-17 .

[22] Musigire, Samuel \& Ntayi, Joseph \& Ahiauzu , Augustine :2017, "Does Strategic ambidexterity moderate organizational support-sales performance relationship for financial services in Uganda? ", African Joural of Business Management, Vol.11 , pp.74-83 .

[23] Nohman, Brula \& Nohman, Sleyman :2015, " Ambidextrity:A matter of size?-A single case study on ambidextrity in SMEs", Master thesis in Business Administration, International Business and Economics Program, Linkoping University .

[24] Open Universiteit Nederland.

[25] Shoba, Sibongile C C. : 2017 , " Organisational ambidextrity in low-fee private schools in South Africa" , The degree of Master of Business Administration, Gordon Institute of Business Science, University of Pretoria .

[26] Zaidi, Mohamad Faizal Ahmad \& Othman, Siti Norezam :2015, "Structural Ambidextrity vs.Contextual Ambidextrity :Preliminary Evidence from Malaysia" , Full Paper Proceeding Multidisciplinary studies, Vol.1, pp.21-34 . 